Review

\title{
Integration of Bioinformatic Predictions and Experimental Data to Identify circRNA-miRNA Associations
}

\author{
Martina Dori * and Silvio Bicciato *(D) \\ Center for Genome Research, Department of Life Sciences, University of Modena and Reggio Emilia, \\ Via G. Campi, 287, 41100 Modena, Italy \\ * Correspondence: martina.dori@unimore.it (M.D.); silvio.bicciato@unimore.it (S.B.)
}

Received: 18 July 2019; Accepted: 21 August 2019; Published: 24 August 2019

\begin{abstract}
Circular RNAs (circRNAs) have recently emerged as a novel class of transcripts, characterized by covalently linked $3^{\prime}-5^{\prime}$ ends that result in the so-called backsplice junction. During the last few years, thousands of circRNAs have been identified in different organisms. Yet, despite their role as disease biomarker started to emerge, depicting their function remains challenging. Different studies have shown that certain circRNAs act as miRNA sponges, but any attempt to generalize from the single case to the "circ-ome" has failed so far. In this review, we explore the potential to define miRNA "sponging" as a more general function of circRNAs and describe the different approaches to predict miRNA response elements (MREs) in known or novel circRNA sequences. Moreover, we discuss how experiments based on Ago2-IP and experimentally validated miRNA:target duplexes can be used to either prioritize or validate putative miRNA-circRNA associations.
\end{abstract}

Keywords: circRNA; miRNA; target prediction; miRNA sponge

\section{Introduction}

During the past decades, the field of RNA biology experienced an incredible evolution dictated by the discovery of long non-coding RNAs, the elucidation of the silencing pathways of short non-coding RNAs and, more importantly, of their regulatory functions [1]. Recently, a new class of non-coding RNAs has taken the scene: circular RNAs (circRNAs) [2]. Interestingly, the existence of RNAs with a circular form has been known for many years, but they were associated only with viruses and viroids (e.g., hepatitis $\delta$ virus [3]). Although few examples of circRNAs from transcribed genes were reported (e.g., Sry, [4-6], DCC [7], CYP450 [8]), only recently their abundance and regulatory functions have been described openly [9-12]. circRNAs consists in covalently closed RNA molecules with the $3^{\prime}$ - and the $5^{\prime}$-ends linked in a non-collinear way resulting in the so-called backsplice junction (Figure 1) [13]. They result from an unusual splicing event that is believed to be mediated either by the pairing of long flanking introns (containing repetitive elements in an inverted orientation) or by an intra-lariat splicing [13-19]. As linear RNA, circRNAs can undergo alternative splicing that generates different classes of circRNAs (intron-containing, single exon, multiple exon, intergenic, intronic) and increases the "circ-ome" overall complexity [12,19-23]. This particular splicing event causes circRNAs to lack the $3^{\prime}$ poly(A) tail and the $5^{\prime}$ capping, a feature that confers resistance to exonuclease activity (e.g., RNase R [24,25]) and results, on average, in a longer half-life as compared to linear RNAs [11]. Since the first reports of circRNAs expression in humans and mice, thousands of potential circular RNAs have been predicted in different species (like Drosophila, Caenorhabditis elegans and plants) $[9,11,12,15,26-32]$. Despite the great attention that this elusive class of ncRNA has gathered, only a handful of transcripts have been fully functionally characterized. Nevertheless, the high stability 
combined with their identification in human body fluids (e.g., plasma [33] and saliva [34]) has greatly increased the interest toward circRNAs as potential disease biomarkers [35] and, following this idea, dozens of studies identified circRNAs in different pathological conditions [36] such as Alzheimer's disease, atherosclerosis, myocardial infarction and, most importantly, cancer [37-42].

In this review, we explore one of the hypothesized functions for circRNA, i.e., miRNA binding. Particularly, we will first address the definition of "sponging", which, so far, has been quite an appealing but misleading term, and then discuss the different computational approaches to predict miRNA-circRNA binding sites and the strategies to prioritize/validate such interactions.
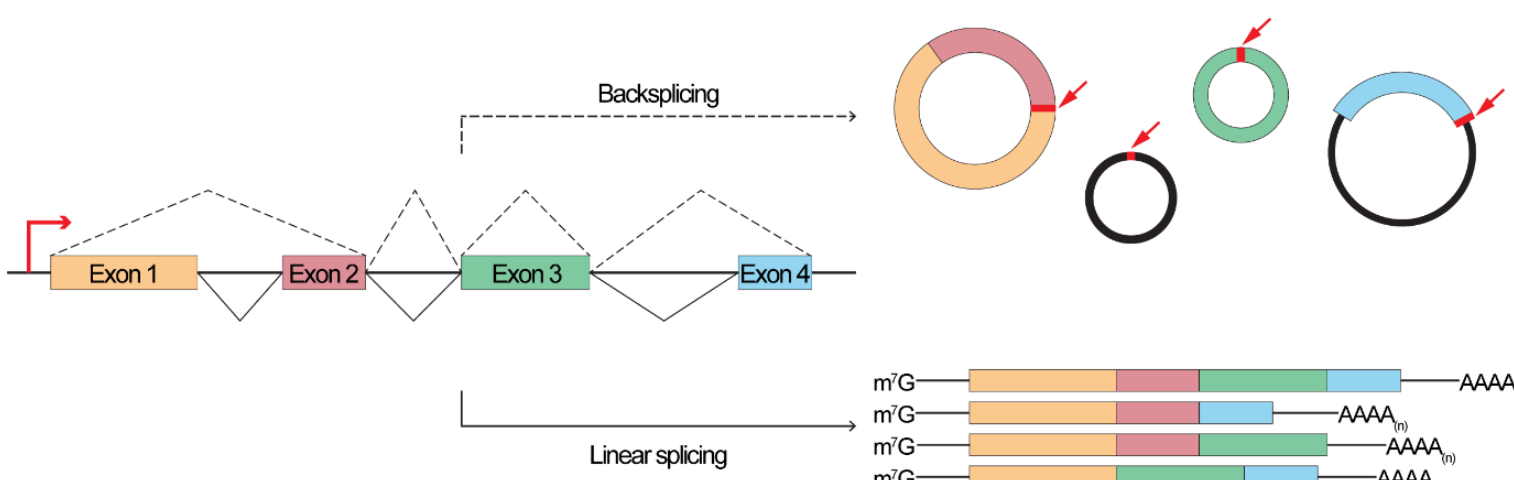

Figure 1. Linear vs Circular splicing. Circular RNAs (circRNAs) are formed from an unusual splicing event that results in covalently linked $3^{\prime}-5^{\prime}$ ends termed as a backsplice junction (top, indicated by a red arrow). As for linear transcripts (bottom), circRNAs can undergo alternative splicing, resulting in different classes of transcripts (mono or multi exonic, intronic, exon-intron structure).

\section{To Sponge or Not to Sponge, That is the Question}

The high stability and the presence in different body fluids make circRNAs extremely promising disease biomarkers. Given their diagnostic relevance, a lot of efforts have been put in the functional characterization of circRNAs, as this is critical to understand their role in disease development or progression and to provide crucial insights into their physiological role. It has been shown that nuclear circRNAs can be involved in regulating mRNA expression at the level of transcription by interacting with RNA polymerase or with members of the spliceosome machinery [43], for example. Conversely, cytoplasmic circRNAs seem to be involved in post-transcriptional regulation, sequester RNA-binding proteins [14,44] or even can be translated into small peptides [45,46]. Considering post-transcriptional regulation, one of the first and most investigated functions of circRNAs is miRNA sponging (Figure 2) $[10,12,38,47,48]$. In fact, in the past couple of years the number of papers involving circRNA-miRNA interaction has grown almost exponentially and, in 2018, represented $\sim 60 \%$ of circRNA-related publications (Figure 3). Despite the increasing number of studies focusing on circRNA-miRNA interactions, to generalize this specific function to the entire "circ-ome" still remains challenging. The first, and most important, issue in this regard is the definition of "sponging" or, more appropriately, of competing endogenous RNAs (ceRNAs). Whether the ceRNAs hypothesis [49] is sufficient to explain the function of thousands of poorly characterized ncRNAs is still an argument worthy of great debate (refer to Thomson and Dinger [50] for more details). Nevertheless, it is crucial to consider the evidence that the expression alone of a ceRNA (in our case specifically, circRNAs) might not be sufficient to have a measurable effect on highly expressed miRNA and, therefore, on its downstream targets [51], while the impact on lowly expressed ones could be more significant [52]. This has a major consequence in the definition of the minimum characteristics that a circRNA must hold (e.g., expression, number of possible miRNA response elements-MREs—and miRNA expression itself) to be considered a miRNA sponge. Taking into account that, overall, circRNAs are expressed at lower levels than other RNAs $[11,12,20,53]$ and that the expression is tissue- and cell-type-specific $[20,23,30,54-57]$, 
the presence of a relatively high number of MREs for the same miRNA within the sequence of a single circular RNA would be expected. Different studies have shown that, beside CDR1as, only a very limited number of circRNA exhibit this property [30,53], pointing strongly toward the idea that sponging is an exception, rather than a general function.

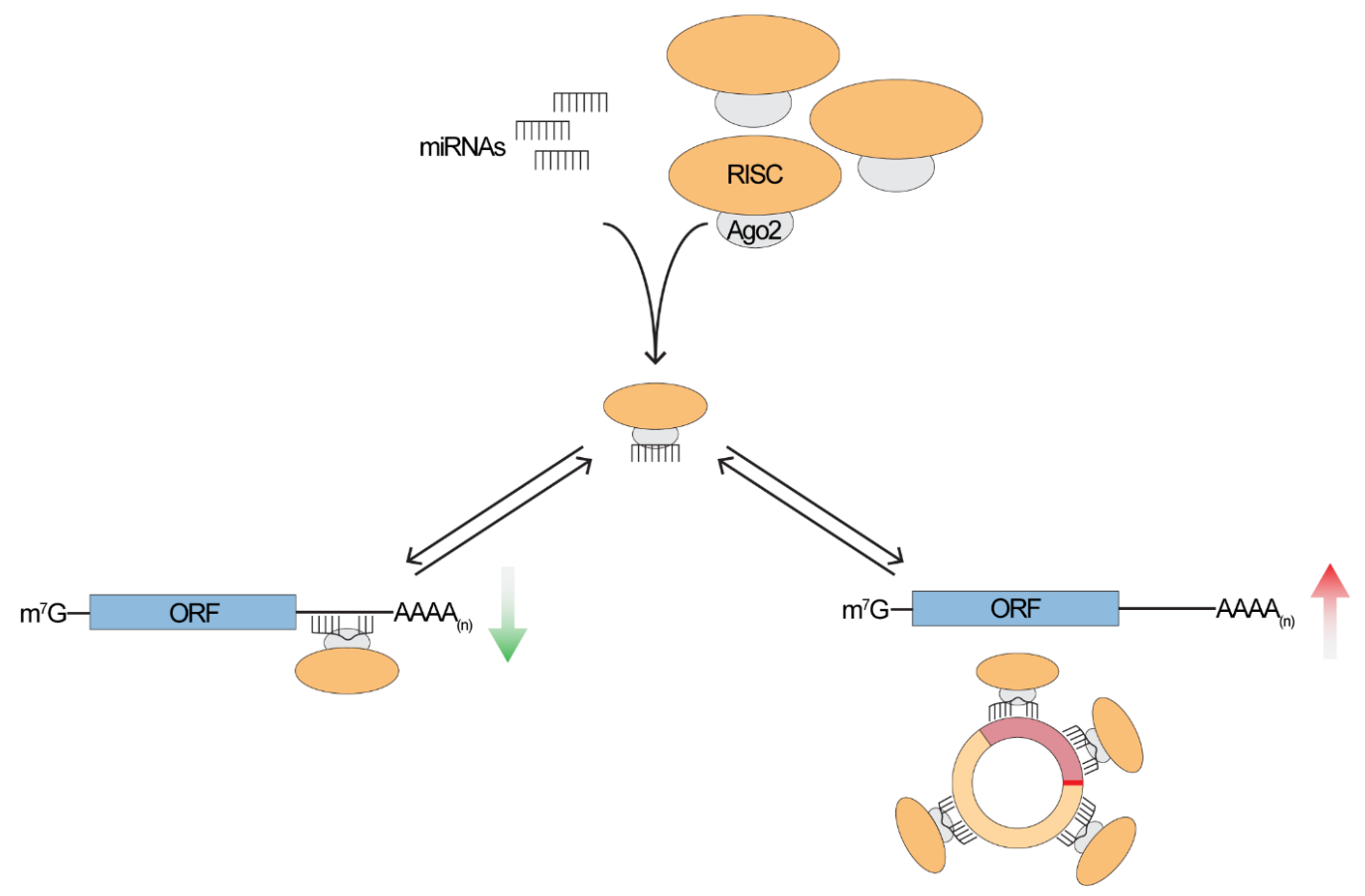

Figure 2. A miRNA-circRNA-mRNA network. It has been proposed that circRNA can act as a miRNA sponge, therefore competing with a linear target for the binding of the RISC complex. In the absence of circRNA, miRNAs are free to bind to their linear target, determining their repression. When the circRNA is expressed, the miRNA will guide the RISC complex to bind the circRNA, ultimately causing the de-repression of the mRNA. mRNA is depicted as an Open Reading Frame (ORF) with a $5^{\prime}$ cap $\left(\mathrm{m}^{7} \mathrm{G}\right)$ and a $3^{\prime}$ poly $(\mathrm{A})$ tail.

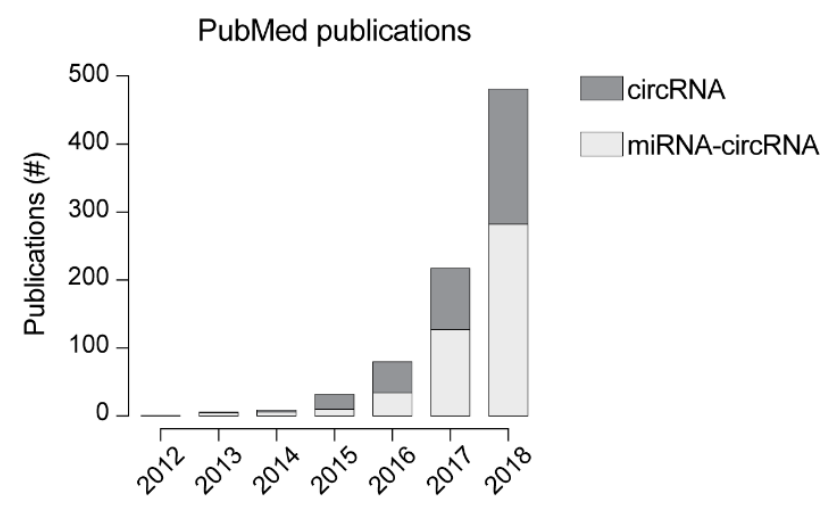

Figure 3. Per year number of publication indexed in PubMed. Dark grey represents the number of publications resulting by the search term "circRNA" while light grey represents the number of papers resulting from the combined search of "circRNA miRNA".

\section{Predicting circRNA-miRNA Binding Sites}

Although circRNAs cannot be considered "sponges", it is clear that these molecules fulfill their regulatory function also through the interaction with miRNAs [58-65]. To this end, knowing the sequence and the expression levels of circRNAs in a given tissue is essential. The most common 
approach to obtain this information is based on microarrays with probes specifically designed to target the most updated collection of human/mouse/rat circRNAs [66,67]. This allows the detection of even very lowly expressed circRNAs with high reproducibility (ideally, down to one copy), and facilitates the identification of differentially expressed circRNAs. Additionally, the development of more sophisticated RNA sequencing protocols (e.g., RPAD [68]) provides the possibility to identify highly pure circRNAs, overcoming the limit of relying only on annotated transcripts. Obviously, in the latter case, not only the sequencing protocol, but also which tool is used to identify the backsplice junction are critical issues and possible sources of variability between experiments [69]. No matter which approach is used for the identification of circRNAs, the bioinformatic prediction of MREs can be done in many different ways, mainly depending whether the circRNA is already known or a novel transcript.

\subsection{Investigating Known circRNAs}

In the past years, several databases have been released with the main goal of collecting all possible information regarding known circRNAs in different species (e.g., circBase [70], Table 1). These databases have expanded to meet the increasing complexity of circRNA expression patterns and to collect all possible information about functional predictions and associations with diseases (e.g., circNet [71], CircInteractome [72], circ2Traits [73]). One of the features that has been included is the miRNAs binding sites for all available circRNAs. These are obtained either using miRNA target prediction tools (as TargetScan [74], RNA22 [75], PITA [76], miRanda/miRSVR [77,78], etc.), like in the case of circNet and CircInteractome, or combining Ago binding sites with miRNA target predictions (as, for instance, starBase v2.0 $[79,80]$ and its most updated version, ENCORI), although these approaches might result in multiple putative miRNAs hits per single circRNA. A possible strategy to reduce the number of candidate circRNA-miRNA associations is to consider also the downstream mRNAs (usually from databases including experimentally validated miRNA targets like TarBase v.8 [81] or miRTarBase [82]) and create a circRNA-miRNA-mRNA network. This procedure builds on the idea that an up-regulated circRNA will cause a down-regulation of its interacting miRNA that will ultimately determine an up-regulation of the target mRNA [83-90]. Networks that satisfy these expression criteria are selected finally for functional validation: first, the MREs predicted within the circRNA are validated primarily by luciferase assay and then the expression of the target miRNA and mRNA are evaluated upon circRNA depletion (or overexpression, according to the initial transcription pattern). Although quite successful, this approach presents some limitations, for instance, the databases providing miRNA binding predictions are dealing only with human circRNAs, with the exception of starBase $[79,80]$ which includes also data for mouse and C. elegans. Additionally, this workflow is effective only when the circRNA has been previously identified and annotated in other databases (like circBase) and, finally, it also requires a differential expression analysis for all components of the network (circRNA, miRNA and mRNA). Moreover, validating MREs with luciferase assay has two major drawbacks: i) it does not always provide a clear proof of direct interaction [91]; and ii) it implies that the MREs on the circRNA have to be sufficiently strong to cause a significant variation in either luminescence or luciferase mRNA levels, which is not necessarily the case. These issues can be overcome by an RNA Immunoprecipitation assay (RIP, [92]) that will provide information of what is directly binding to the circRNA, with no regard to a functional output [93-100]. 
Table 1. List of relevant circRNA-related databases including the available organisms and their general features.

\begin{tabular}{|c|c|c|c|}
\hline Database & Website & Organisms & Features \\
\hline circBase & http://www.circbase.org & $\begin{array}{l}\text { Human } \\
\text { Mouse } \\
\text { Fly } \\
\text { Worm } \\
\text { Fish } \\
\text { Planaria }\end{array}$ & $\begin{array}{l}\text { Most updated catalogue of } \\
\text { predicted circRNAs. Beside } \\
\text { human and mouse, it also } \\
\text { collects data from several other } \\
\text { organisms }\end{array}$ \\
\hline circInteractome & https://circinteractome.nia.nih.gov & Human & $\begin{array}{l}\text { Enables the prediction and } \\
\text { mapping of binding sites for } \\
\text { RNA binding proteins and } \\
\text { miRNA on known circRNAs. } \\
\text { It includes also a module for } \\
\text { siRNA design for knock-down } \\
\text { experiments and primer design } \\
\text { for PCR }\end{array}$ \\
\hline circNet & http://syslab5.nchu.edu.tw/CircNet/ & Human & $\begin{array}{l}\text { Provides tissue-specific } \\
\text { expression patterns, integrated } \\
\text { miRNA-circRNA-mRNA } \\
\text { networks, circRNA isoform } \\
\text { expression and genomic } \\
\text { annotation }\end{array}$ \\
\hline $\begin{array}{c}\text { ENCORI } \\
\text { StarBase v2 }\end{array}$ & $\begin{array}{l}\text { http://starbase.sysu.edu.cn/index.php } \\
\text { http://starbase.sysu.edu.cn/starbase2/ } \\
\text { index.php }\end{array}$ & $\begin{array}{l}\text { Human } \\
\text { Mouse } \\
\text { Worm }\end{array}$ & $\begin{array}{l}\text { Designed for investigating } \\
\text { interaction networks of } \\
\text { lncRNAs, miRNAs, ceRNA, } \\
\text { RNA binding proteins and } \\
\text { mRNAs from public CLIP-Seq } \\
\text { data. It also allows to browse for } \\
\text { circRNA-miRNA interactions. }\end{array}$ \\
\hline circ2Traits & http://gyanxet-beta.com/circdb/ & Human & $\begin{array}{l}\text { Link of circRNA with disease } \\
\text { inferred by miRNA-disease } \\
\text { associations }\end{array}$ \\
\hline
\end{tabular}

\subsection{Characterizing Novel circRNAs}

As mentioned previously, circRNAs have been shown to have a time- and tissue-specific expression pattern $[20,23,30]$. This results in the need, due to the complexity of organisms, to perform comprehensive assessments to investigate specific tissues and developmental stages. The best way to address this issue is through RNA sequencing, since this method is not limited by an a priori knowledge of circRNA sequences and expression. In turn, when it comes to MREs prediction, the bioinformatic approach becomes less straightforward. Assuming that the full sequence of novel circRNAs has been assessed, the first issue is represented by the choice of an appropriate tool to predict MREs. Although it has been shown that more than $80 \%$ of circRNAs are overlapping coding genes, less than $10 \%$ include a 3'UTR, making it almost useless to take advantage of available databases (like TargetScan [74], Table 2) that contain information on $3^{\prime}$ UTRs only. On the other hand, databases that provide information on MREs on the entire sequence (e.g., microRNA.org [101]) and also include experimental validation information (like TarBase v8 [81] or STarMirDB [102]) do not allow to browse by target sequence in addition to gene name, therefore becoming useless for the analysis of novel circRNAs. There are some tools that have been designed to also search by custom sequences (e.g., STarMir [103]), but they show limitation in the length of the queried sequence, allowing the analysis only of few transcripts and making it difficult to perform a comprehensive assessment. One way to overcome these limitations is to use the stand-alone versions of the algorithms behind the prediction database (when available). Thus, the direct application of the algorithms allows the analysis of any given sequence for any given list of miRNAs. Unfortunately, results obtained with this approach show an extremely high rate of 
false positives, requiring either a systematic validation of the targets (e.g., with RIP assays) or the integration with known interactions.

Table 2. List of the most common databases and algorithms for predicting miRNA binding sites together with the organisms for which the prediction can be browsed (by sequence and/or by gene ID) and if they share the standalone version.

\begin{tabular}{|c|c|c|c|c|}
\hline Tool & Website & Organisms & $\begin{array}{c}\text { Browse by } \\
\text { Sequenc/Gene ID }\end{array}$ & $\begin{array}{l}\text { Standalone } \\
\text { Version }\end{array}$ \\
\hline STarMir & $\begin{array}{l}\text { http://sfold.wadsworth.org/ } \\
\text { cgi-bin/starmirtest2.pl }\end{array}$ & $\begin{array}{l}\text { Human } \\
\text { Mouse } \\
\text { Worm } \\
\text { Other }\end{array}$ & $\begin{array}{l}\text { Sequence/ } \\
\text { Gene ID }\end{array}$ & no \\
\hline STarMirDB & $\begin{array}{l}\text { http://sfold.wadsworth.org/ } \\
\text { starmirDB.php }\end{array}$ & $\begin{array}{l}\text { Human } \\
\text { Mouse } \\
\text { Worm }\end{array}$ & Gene ID & no \\
\hline PITA & $\begin{array}{l}\text { https://genie.weizmann.ac.il/ } \\
\text { pubs/mir07/index.html }\end{array}$ & $\begin{array}{l}\text { Human } \\
\text { Mouse } \\
\text { Fly } \\
\text { Worm }\end{array}$ & Gene ID & yes \\
\hline $\begin{array}{l}\text { miRanda/ } \\
\text { mirSVR }\end{array}$ & $\begin{array}{l}\text { http://www.microrna.org/ } \\
\text { microrna/home.do }\end{array}$ & $\begin{array}{l}\text { Human } \\
\text { Mouse } \\
\text { Rat } \\
\text { Fly } \\
\text { Worm }\end{array}$ & Gene ID & yes \\
\hline TargetScan & $\begin{array}{c}\text { http: } \\
\text { //www.targetscan.org/vert_72/ }\end{array}$ & $\begin{array}{l}\text { Human } \\
\text { Mouse } \\
\text { Fly } \\
\text { Worm } \\
\text { Zebrafish }\end{array}$ & Gene ID & yes \\
\hline RNAhybrid & $\begin{array}{l}\text { https://bibiserv.cebitec.uni- } \\
\text { bielefeld.de/rnahybrid/ }\end{array}$ & Any & Sequence & yes \\
\hline TarBase v8 & $\begin{array}{l}\text { http://carolina.imis.athena- } \\
\text { innovation.gr/diana_tools/ } \\
\text { web/index.php }\end{array}$ & $\begin{array}{c}\text { Human } \\
\text { Mouse } \\
\text { Rat } \\
\text { Chicken } \\
\text { Zebrafish } \\
\text { Fly } \\
\text { Worm } \\
\text { Chimpanzees } \\
\text { Macaque } \\
\text { Soy } \\
\text { Maize } \\
\text { Barrelclover } \\
\text { Grape wine } \\
\text { Earthmoss } \\
\text { Epstein-Barr } \\
\text { virus } \\
\text { KSHV }\end{array}$ & Gene ID & no \\
\hline
\end{tabular}

\section{Integrating Seed Prediction on Custom Sequences with Experimental Data}

No matter which method is used to design the prediction algorithm, the major reason behind the high rate of observed false positives and false negatives is the fact that miRNA-target recognition already is effective with a seed length of six nucleotides [104,105]. Reducing and prioritizing the predicted interaction is not trivial, as each possible approach has several pros and cons. For example, to consider conservation of seed and MREs across species dramatically reduces the number of predictions, although 
this approach does not consider non-canonical, as well as non-conserved, binding sites [106]. Moreover, using the free energy of miRNA:target duplexes is effective at the cost of an incredibly high number of putative very stable false positive interactions. Given that no gold standard has been identified nor do any algorithms outperform the others, there are some steps that can be undertaken to "manually" predict circRNA-miRNA sites while limiting the possibly overwhelming list of predicted binding interactions. This workflow (depicted in Figure 4, left) can be divided into three main steps. To show how each step influences the final outcome, we analyzed 100 randomly chosen mouse circRNA from previous work [30]. As done in some databases for gene-miRNA target mining (e.g., miRWalk [107]), the first step consists in performing the analysis with the same input (circRNAs) and miRNA sequences using different algorithms (for this example, TargetScan [74], miRanda [77] and RNAhybrid [108] were used, Figure 4, right). Using default options, we obtained for our cohort of circRNAs an average of 115,747 putative MREs where RNAhybrid predicted the highest number of sites $(183,954)$ while miRanda the lowest $(68,790)$. The second step consists in retrieving only the predictions that have been identified by at least half of the programs (in our case we selected MREs predicted by at least two programs). This first filtering step reduced the initial list to approximately 23,000 MREs, with only 1935 sites predicted by all programs. In particularly, for TargetScan only $\sim 19 \%$ of predicted sites were common to at least another algorithm, while for miRanda the sites were reduced to approximately $30 \%$. Regarding RNAhybrid, we observed the most severe reduction, as only $5 \%$ of all the predicted MREs were kept for the last step. To further reduce the amount of possible false positives, a valid approach is to make use of complementary experimental data. Specifically, since the binding of the RISC complex is mediated by the interaction of the miRNA with members of the Argonaute protein family $[109,110]$, it is fundamental, for a predicted miRNA-circRNA site to be real, that Ago proteins also are binding in the same positions. The development of various CLIP-Seq protocols (Cross-linking and Immunoprecipitation followed by sequencing) provides an extremely valuable source of high-throughput data of Ago binding sites [111-117]. These data can be directly used to eliminate all the predicted sites for which there is no binding of Ago protein [118], considering this a sine qua non condition for a true binding of miRNA on the target circRNA. Considering this, the last step consists in the retrieval of all the MREs that are overlapped also by Ago and to this end we used a collection of publicly available Ago-binding sites from mouse brains [115,119]. We obtained a final set of 2257 sites partially overlapping an Ago peak and among these, 1091 MREs were included entirely in a peak. Using this final filtering, we could reduce the number of putative circRNA:miRNA sites down to $0.9 \%$ and $1.5 \%$ for TargetScan and miRanda predictions, respectively. Again, the most dramatic decrease was observed for RNAhybrid predictions as only $0.2 \%$ of MREs were included in the final list. Since Ago CLIP-Seq experiments are not available for all cell types, tissues and organisms, for this last step accessible data also can be used indirectly, for instance, by creating a pool of Ago-binding motifs and exploiting sequence similarity to quantify existence probability of custom miRNA:circRNA duplexes.

\section{Ranking MREs}

The approach presented in this example uses a basic step-wise filtering system that takes the output of different prediction programs and sequentially reduces the pool of MREs according to the presence/absence of specific criteria (prediction by at least 2 out of 3 algorithms; overlap with an Ago peak). As shown, this system already is effective in reducing the amount of data that can be considered for further validation and functional characterization, but we still might be missing valuable information given by the pool of MREs that are specific to each algorithm but that still overlap an Ago peak ( 12,000 additional MREs in total). To overcome this limitation, a possible alternative is the construction of a scoring function that evaluates the probability of a predicted MRE to be real by considering the validated data (presence of an Ago peak/binding motif) and the initial prediction information (observation that the same site is identified by one or more algorithms) [120]. Weighting these two aspects differently, the resulting score would allow the ranking of all predicted MREs and to 
prioritize those that include both the experimental data and the predictions by multiple algorithms while not excluding all the sites identified by single programs that still retain a correspondence among validated data.
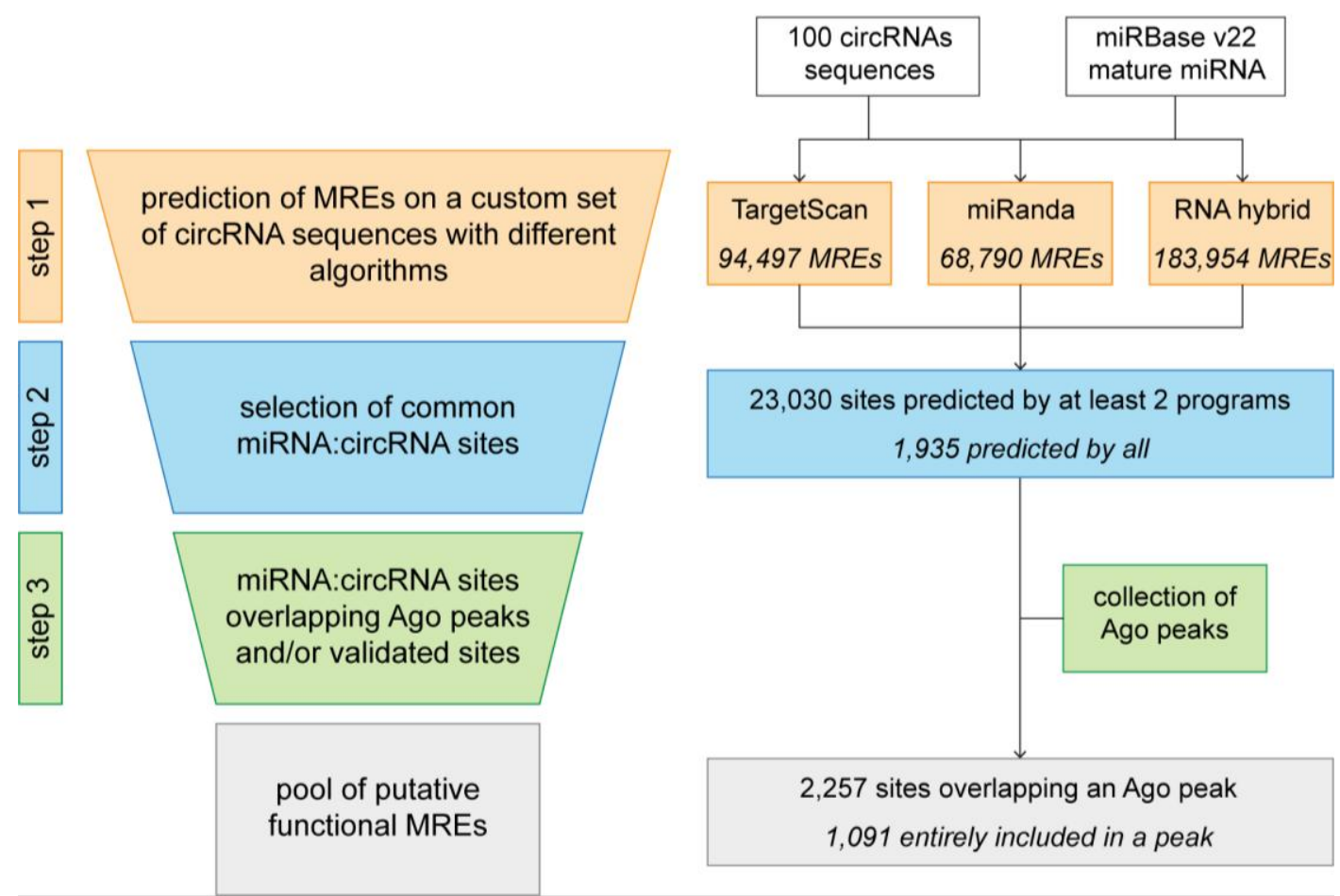

Figure 4. A possible pipeline for the comprehensive assessment of circRNA:miRNA binding sites starting from a custom set of expressed circRNA sequences (left) and a practical example on the outcome of each step on a set of randomly chosen sequences from previous work [30] (right).

\section{Concluding Remarks}

Circular RNAs have recently emerged as a novel class of transcripts characterized by covalently linked $3^{\prime}-5^{\prime}$ ends called backsplice junctions. Studies have shown their relevance in physiological and pathological conditions, in particular as disease biomarkers and potential therapeutic targets. However, the functional characterization of these sequences is still in its infancy and the role of relatively few circRNAs has been described to date. Recently, great effort has been put toward understanding one specific mechanism, i.e., miRNA sponging. Due to the combined overall low expression of circRNAs and the low number of MREs predicted within their sequence, only a handful of transcripts really can be considered true "sponges". Nevertheless, it is undeniable that circRNAs are capable of binding miRNAs but, more than a "sponge" for a single small RNA, they might function as a scaffold for several different ones. Regarding this, it is crucial to develop appropriate pipelines that allow a more accurate prediction of the miRNA targets, thus facilitating an overall assessment of miRNA binding and, possibly, leading to the identification of a more general function.

Author Contributions: M.D. conceived the project; M.D. and S.B. wrote and revised the manuscript.

Funding: This work was funded by the Italian Epigenomics Flagship Project (Epigen).

Acknowledgments: We thank members of our lab for helpful discussion and suggestion.

Conflicts of Interest: The authors declare no conflict of interest. 


\section{References}

1. Carthew, R.W.; Sontheimer, E.J. Origins and mechanisms of miRNAs and siRNAs. Cell 2009, 136, $642-655$. [CrossRef] [PubMed]

2. Kosik, K.S. Circles reshape the RNA world. Nature 2013, 495, 322-324. [CrossRef] [PubMed]

3. Kos, A.; Dijkema, R.; Arnberg, A.C.; van der Meide, P.H.; Schellekens, H. The hepatitis delta ( $\delta)$ virus possesses a circular RNA. Nature 1986, 323, 558. [CrossRef] [PubMed]

4. Capel, B.; Swain, A.; Nicolis, S.; Hacker, A.; Walter, M.; Koopman, P.; Goodfellow, P.; Lovell-Badge, R. Circular transcripts of the testis-determining gene Sry in adult mouse testis. Cell 1993, 73, 1019-1030. [CrossRef]

5. Hacker, A.; Capel, B.; Goodfellow, P.; Lovell-Badge, R. Expression of Sry, the mouse sex determining gene. Development 1995, 121, 1603-1614. [PubMed]

6. Jeske, Y.W.; Bowles, J.; Greenfield, A.; Koopman, P. Expression of a linear Sry transcript in the mouse genital ridge. Nat. Genet. 1995, 10, 480-482. [CrossRef] [PubMed]

7. Nigro, J.M.; Cho, K.R.; Fearon, E.R.; Kern, S.E.; Ruppert, J.M.; Oliner, J.D.; Kinzler, K.W.; Vogelstein, B. Scrambled exons. Cell 1991, 64, 607-613. [CrossRef]

8. Zaphiropoulos, P.G. Circular RNAs from transcripts of the rat cytochrome P450 2C24 gene: Correlation with exon skipping. Proc. Natl. Acad. Sci. USA 1996, 93, 6536-6541. [CrossRef]

9. Salzman, J.; Gawad, C.; Wang, P.L.; Lacayo, N.; Brown, P.O. Circular RNAs are the predominant transcript isoform from hundreds of human genes in diverse cell types. PLoS ONE 2012, 7, e30733. [CrossRef]

10. Hansen, T.B.; Jensen, T.I.; Clausen, B.H.; Bramsen, J.B.; Finsen, B.; Damgaard, C.K.; Kjems, J. Natural RNA circles function as efficient microRNA sponges. Nature 2013, 495, 384-388. [CrossRef]

11. Jeck, W.R.; Sorrentino, J.A.; Wang, K.; Slevin, M.K.; Burd, C.E.; Liu, J.; Marzluff, W.F.; Sharpless, N.E. Circular RNAs are abundant, conserved, and associated with ALU repeats. RNA 2013, 19, 141-157. [CrossRef] [PubMed]

12. Memczak, S.; Jens, M.; Elefsinioti, A.; Torti, F.; Krueger, J.; Rybak, A.; Maier, L.; Mackowiak, S.D.; Gregersen, L.H.; Munschauer, M.; et al. Circular RNAs are a large class of animal RNAs with regulatory potency. Nature 2013, 495, 333-338. [CrossRef] [PubMed]

13. Lasda, E.; Parker, R. Circular RNAs: Diversity of form and function. RNA 2014, 20, 1829-1842. [CrossRef] [PubMed]

14. Ashwal-Fluss, R.; Meyer, M.; Pamudurti, N.R.; Ivanov, A.; Bartok, O.; Hanan, M.; Evantal, N.; Memczak, S.; Rajewsky, N.; Kadener, S. circRNA biogenesis competes with pre-mRNA splicing. Mol. Cell 2014, 56, 55-66. [CrossRef] [PubMed]

15. Ivanov, A.; Memczak, S.; Wyler, E.; Torti, F.; Porath, H.T.; Orejuela, M.R.; Piechotta, M.; Levanon, E.Y.; Landthaler, M.; Dieterich, C.; et al. Analysis of intron sequences reveals hallmarks of circular RNA biogenesis in animals. Cell Rep. 2015, 10, 170-177. [CrossRef] [PubMed]

16. Starke, S.; Jost, I.; Rossbach, O.; Schneider, T.; Schreiner, S.; Hung, L.H.; Bindereif, A. Exon circularization requires canonical splice signals. Cell Rep. 2015, 10, 103-111. [CrossRef] [PubMed]

17. Wang, Y.; Wang, Z. Efficient backsplicing produces translatable circular mRNAs. RNA 2015, 21, $172-179$. [CrossRef]

18. Conn, S.J.; Pillman, K.A.; Toubia, J.; Conn, V.M.; Salmanidis, M.; Phillips, C.A.; Roslan, S.; Schreiber, A.W.; Gregory, P.A.; Goodall, G.J. The RNA binding protein quaking regulates formation of circRNAs. Cell 2015, 160, 1125-1134. [CrossRef]

19. Zhang, X.O.; Dong, R.; Zhang, Y.; Zhang, J.L.; Luo, Z.; Zhang, J.; Chen, L.L.; Yang, L. Diverse alternative back-splicing and alternative splicing landscape of circular RNAs. Genome Res. 2016, 26, 1277-1287. [CrossRef]

20. Salzman, J.; Chen, R.E.; Olsen, M.N.; Wang, P.L.; Brown, P.O. Cell-type specific features of circular RNA expression. PLoS Genet. 2013, 9, e1003777. [CrossRef]

21. Zhang, Y.; Zhang, X.O.; Chen, T.; Xiang, J.F.; Yin, Q.F.; Xing, Y.H.; Zhu, S.; Yang, L.; Chen, L.L. Circular intronic long noncoding RNAs. Mol. Cell 2013, 51, 792-806. [CrossRef]

22. Li, F.; Zhang, L.; Li, W.; Deng, J.; Zheng, J.; An, M.; Lu, J.; Zhou, Y. Circular RNA ITCH has inhibitory effect on ESCC by suppressing the Wnt/ $\beta$-catenin pathway. Oncotarget 2015, 6, 6001-6013. [CrossRef] 
23. Rybak-Wolf, A.; Stottmeister, C.; Glazar, P.; Jens, M.; Pino, N.; Giusti, S.; Hanan, M.; Behm, M.; Bartok, O.; Ashwal-Fluss, R.; et al. Circular RNAs in the mammalian brain are highly abundant, conserved, and dynamically expressed. Mol. Cell 2015, 58, 870-885. [CrossRef]

24. Suzuki, H.; Zuo, Y.; Wang, J.; Zhang, M.Q.; Malhotra, A.; Mayeda, A. Characterization of RNase R-digested cellular RNA source that consists of lariat and circular RNAs from pre-mRNA splicing. Nucleic Acids Res. 2006, 34, e63. [CrossRef]

25. Vincent, H.A.; Deutscher, M.P. Substrate recognition and catalysis by the exoribonuclease RNase R. J. Biol. Chem. 2006, 281, 29769-29775. [CrossRef]

26. Westholm, J.O.; Miura, P.; Olson, S.; Shenker, S.; Joseph, B.; Sanfilippo, P.; Celniker, S.E.; Graveley, B.R.; Lai, E.C. Genome-wide analysis of drosophila circular RNAs reveals their structural and sequence properties and age-dependent neural accumulation. Cell Rep. 2014, 9, 1966-1980. [CrossRef]

27. Conn, V.M.; Hugouvieux, V.; Nayak, A.; Conos, S.A.; Capovilla, G.; Cildir, G.; Jourdain, A.; Tergaonkar, V.; Schmid, M.; Zubieta, C.; et al. A circRNA from SEPALLATA3 regulates splicing of its cognate mRNA through R-loop formation. Nat. Plants 2017, 3, 17053. [CrossRef]

28. Tang, B.; Hao, Z.; Zhu, Y.; Zhang, H.; Li, G. Genome-wide identification and functional analysis of circRNAs in Zea mays. PLoS ONE 2018, 13, e0202375. [CrossRef]

29. Wang, Y.; Gao, Y.; Zhang, H.; Wang, H.; Liu, X.; Xu, X.; Zhang, Z.; Kohnen, M.V.; Hu, K.; Wang, H.; et al. Genome-wide profiling of circular RNAs in the rapidly growing shoots of moso bamboo (Phyllostachys edulis). Plant Cell Physiol. 2019, 60, 1354-1373. [CrossRef]

30. Dori, M.; Haj Abdullah Alieh, L.; Cavalli, D.; Massalini, S.; Lesche, M.; Dahl, A.; Calegari, F. Sequence and expression levels of circular RNAs in progenitor cell types during mouse corticogenesis. Life Sci. Alliance 2019, 2, e201900354. [CrossRef]

31. Ragan, C.; Goodall, G.J.; Shirokikh, N.E.; Preiss, T. Insights into the biogenesis and potential functions of exonic circular RNA. Sci. Rep. 2019, 9, 2048. [CrossRef]

32. Xu, K.; Chen, D.; Wang, Z.; Ma, J.; Zhou, J.; Chen, N.; Lv, L.; Zheng, Y.; Hu, X.; Zhang, Y.; et al. Annotation and functional clustering of circRNA expression in rhesus macaque brain during aging. Cell Discov. 2018, 4, 48. [CrossRef]

33. Li, P.; Chen, S.; Chen, H.; Mo, X.; Li, T.; Shao, Y.; Xiao, B.; Guo, J. Using circular RNA as a novel type of biomarker in the screening of gastric cancer. Clin. Chim. Acta 2015, 444, 132-136. [CrossRef]

34. Bahn, J.H.; Zhang, Q.; Li, F.; Chan, T.M.; Lin, X.; Kim, Y.; Wong, D.T.; Xiao, X. The landscape of microRNA, Piwi-interacting RNA, and circular RNA in human saliva. Clin. Chem. 2015, 61, 221-230. [CrossRef]

35. Memczak, S.; Papavasileiou, P.; Peters, O.; Rajewsky, N. Identification and characterization of circular RNAs as a new class of putative biomarkers in human blood. PLOS ONE 2015, 10, e0141214. [CrossRef]

36. Lyu, D.; Huang, S. The emerging role and clinical implication of human exonic circular RNA. RNA Biol. 2017, 14, 1000-1006. [CrossRef]

37. Holdt, L.M.; Stahringer, A.; Sass, K.; Pichler, G.; Kulak, N.A.; Wilfert, W.; Kohlmaier, A.; Herbst, A.; Northoff, B.H.; Nicolaou, A.; et al. Circular non-coding RNA ANRIL modulates ribosomal RNA maturation and atherosclerosis in humans. Nat. Commun. 2016, 7, 12429. [CrossRef]

38. Hansen, T.B.; Kjems, J.; Damgaard, C.K. Circular RNA and miR-7 in cancer. Cancer Res. 2013, 73, 5609-5612. [CrossRef]

39. Haque, S.; Harries, L.W. Circular RNAs (circRNAs) in health and disease. Genes 2017, 8, 353. [CrossRef]

40. Abu, N.; Jamal, R. Circular RNAs as promising biomarkers: A mini-review. Front. Physiol. 2016, 7, 355. [CrossRef]

41. Bonizzato, A.; Gaffo, E.; Te Kronnie, G.; Bortoluzzi, S. CircRNAs in hematopoiesis and hematological malignancies. Blood Cancer J. 2016, 6, e483. [CrossRef]

42. Kulcheski, F.R.; Christoff, A.P.; Margis, R. Circular RNAs are miRNA sponges and can be used as a new class of biomarker. J. Biotechnol. 2016, 238, 42-51. [CrossRef]

43. Li, Z.; Huang, C.; Bao, C.; Chen, L.; Lin, M.; Wang, X.; Zhong, G.; Yu, B.; Hu, W.; Dai, L.; et al. Exon-intron circular RNAs regulate transcription in the nucleus. Nat. Struct. Mol. Biol. 2015, 22, 256-264. [CrossRef]

44. Du, W.W.; Yang, W.; Liu, E.; Yang, Z.; Dhaliwal, P.; Yang, B.B. Foxo3 circular RNA retards cell cycle progression via forming ternary complexes with p21 and CDK2. Nucleic Acids Res. 2016, 44, 2846-2858. [CrossRef] 
45. Legnini, I.; Di Timoteo, G.; Rossi, F.; Morlando, M.; Briganti, F.; Sthandier, O.; Fatica, A.; Santini, T.; Andronache, A.; Wade, M.; et al. Circ-ZNF609 Is a Circular rna that can be translated and functions in myogenesis. Mol. Cell 2017, 66, 22-37.e29. [CrossRef]

46. Pamudurti, N.R.; Bartok, O.; Jens, M.; Ashwal-Fluss, R.; Stottmeister, C.; Ruhe, L.; Hanan, M.; Wyler, E.; Perez-Hernandez, D.; Ramberger, E.; et al. Translation of CircRNAs. Mol. Cell 2017, 66, 9-21.e27. [CrossRef]

47. Huang, S.; Yang, B.; Chen, B.J.; Bliim, N.; Ueberham, U.; Arendt, T.; Janitz, M. The emerging role of circular RNAs in transcriptome regulation. Genomics 2017, 109, 401-407. [CrossRef]

48. Verduci, L.; Strano, S.; Yarden, Y.; Blandino, G. The circRNA-microRNA code: Emerging implications for cancer diagnosis and treatment. Mol. Oncol. 2019, 13, 669-680. [CrossRef]

49. Salmena, L.; Poliseno, L.; Tay, Y.; Kats, L.; Pandolfi, P.P. A ceRNA hypothesis: The Rosetta Stone of a hidden RNA language? Cell 2011, 146, 353-358. [CrossRef]

50. Thomson, D.W.; Dinger, M.E. Endogenous microRNA sponges: Evidence and controversy. Nat. Rev. Genet. 2016, 17, 272-283. [CrossRef]

51. Denzler, R.; Agarwal, V.; Stefano, J.; Bartel, D.P.; Stoffel, M. Assessing the ceRNA hypothesis with quantitative measurements of miRNA and target abundance. Mol. Cell 2014, 54, 766-776. [CrossRef]

52. Bosson, A.D.; Zamudio, J.R.; Sharp, P.A. Endogenous miRNA and target concentrations determine susceptibility to potential ceRNA competition. Mol. Cell 2014, 56, 347-359. [CrossRef]

53. Guo, J.U.; Agarwal, V.; Guo, H.; Bartel, D.P. Expanded identification and charachterization of mammalian circular RNAs. Genome Biol. 2014, 15, 409. [CrossRef]

54. Alhasan, A.A.; Izuogu, O.G.; Al-Balool, H.H.; Steyn, J.S.; Evans, A.; Colzani, M.; Ghevaert, C.; Mountford, J.C.; Mareneah, L.; Elliott, D.J.; et al. Circular RNA enrichment in platelets is a signature of transcriptome degradation. Blood 2016, 127, e1-e11. [CrossRef]

55. Piwecka, M.; Glazar, P.; Hernandez-Miranda, L.R.; Memczak, S.; Wolf, S.A.; Rybak-Wolf, A.; Filipchyk, A.; Klironomos, F.; Cerda Jara, C.A.; Fenske, P.; et al. Loss of a mammalian circular RNA locus causes miRNA deregulation and affects brain function. Science 2017, 357, eaam8526. [CrossRef]

56. Kaur, S.; Mirza, A.H.; Pociot, F. Cell type-selective expression of circular RNAs in human pancreatic islets. Noncoding RNA 2018, 4, 38. [CrossRef]

57. Holdt, L.M.; Kohlmaier, A.; Teupser, D. Molecular functions and specific roles of circRNAs in the cardiovascular system. Noncoding RNA Res. 2018, 3, 75-98. [CrossRef]

58. Wang, G.; Liu, W.; Zou, Y.; Wang, G.; Deng, Y.; Luo, J.; Zhang, Y.; Li, H.; Zhang, Q.; Yang, Y.; et al. Three isoforms of exosomal circPTGR1 promote hepatocellular carcinoma metastasis via the miR449a-MET pathway. EBioMedicine 2019, 40, 432-445. [CrossRef]

59. Zhang, Y.; Liu, H.; Li, W.; Yu, J.; Shen, Z.; Ye, G.; Qi, X.; Li, G. CircRNA_100269 is downregulated in gastric cancer and suppresses tumor cell growth by targeting miR-630. Aging 2017, 9, 1585-1594. [CrossRef]

60. Wang, W.L.; Yang, Z.; Zhang, Y.J.; Lu, P.; Ni, Y.K.; Sun, C.F.; Liu, F.Y. Competing endogenous RNA analysis reveals the regulatory potency of circRNA_036186 in HNSCC. Int. J. Oncol. 2018, 53, 1529-1543. [CrossRef]

61. Jost, I.; Shalamova, L.A.; Gerresheim, G.K.; Niepmann, M.; Bindereif, A.; Rossbach, O. Functional sequestration of microRNA-122 from Hepatitis C Virus by circular RNA sponges. RNA Biol. 2018, 15, 1032-1039. [CrossRef]

62. Wang, K.; Gan, T.Y.; Li, N.; Liu, C.Y.; Zhou, L.Y.; Gao, J.N.; Chen, C.; Yan, K.W.; Ponnusamy, M.; Zhang, Y.H.; et al. Circular RNA mediates cardiomyocyte death via miRNA-dependent upregulation of MTP18 expression. Cell Death Differ. 2017, 24, 1111-1120. [CrossRef]

63. Wang, R.; Zhang, S.; Chen, X.; Li, N.; Li, J.; Jia, R.; Pan, Y.; Liang, H. CircNT5E acts as a sponge of miR-422a to promote glioblastoma tumorigenesis. Cancer Res. 2018, 78, 4812-4825. [CrossRef]

64. Zhang, F.; Zhang, R.; Zhang, X.; Wu, Y.; Li, X.; Zhang, S.; Hou, W.; Ding, Y.; Tian, J.; Sun, L.; et al. Comprehensive analysis of circRNA expression pattern and circRNA-miRNA-mRNA network in the pathogenesis of atherosclerosis in rabbit. Aging 2018, 10, 2266-2283. [CrossRef]

65. Cai, X.; Zhao, Z.; Dong, J.; Lv, Q.; Yun, B.; Liu, J.; Shen, Y.; Kang, J.; Li, J. Circular RNA circBACH2 plays a role in papillary thyroid carcinoma by sponging miR-139-5p and regulating LMO4 expression. Cell Death Dis. 2019, 10, 184. [CrossRef]

66. Go Beyond RNA. Available online: https://www.arraystar.com/circular-rna-research/ (accessed on 15 May 2019). 
67. Li, S.; Teng, S.; Xu, J.; Su, G.; Zhang, Y.; Zhao, J.; Zhang, S.; Wang, H.; Qin, W.; Lu, Z.J.; et al. Microarray is an efficient tool for circRNA profiling. Brief. Bioinform. 2018. [CrossRef]

68. Pandey, P.R.; Rout, P.K.; Das, A.; Gorospe, M.; Panda, A.C. RPAD (RNase R treatment, polyadenylation, and poly(A)+ RNA depletion) method to isolate highly pure circular RNA. Methods 2019, 155, 41-48. [CrossRef]

69. Hansen, T.B.; Veno, M.T.; Damgaard, C.K.; Kjems, J. Comparison of circular RNA prediction tools. Nucleic Acids Res. 2016, 44, e58. [CrossRef]

70. Glazar, P.; Papavasileiou, P.; Rajewsky, N. circBase: A database for circular RNAs. RNA 2014, 20, 1666-1670. [CrossRef]

71. Liu, Y.C.; Li, J.R.; Sun, C.H.; Andrews, E.; Chao, R.F.; Lin, F.M.; Weng, S.L.; Hsu, S.D.; Huang, C.C.; Cheng, C.; et al. CircNet: A database of circular RNAs derived from transcriptome sequencing data. Nucleic Acids Res. 2016, 44, D209-D215. [CrossRef]

72. Dudekula, D.B.; Panda, A.C.; Grammatikakis, I.; De, S.; Abdelmohsen, K.; Gorospe, M. CircInteractome: A web tool for exploring circular RNAs and their interacting proteins and microRNAs. RNA Biol. 2016, 13, 34-42. [CrossRef]

73. Ghosal, S.; Das, S.; Sen, R.; Basak, P.; Chakrabarti, J. Circ2Traits: A comprehensive database for circular RNA potentially associated with disease and traits. Front. Genet. 2013, 4, 283. [CrossRef]

74. Agarwal, V.; Bell, G.W.; Nam, J.W.; Bartel, D.P. Predicting effective microRNA target sites in mammalian mRNAs. Elife 2015, 4, e05005. [CrossRef]

75. Miranda, K.C.; Huynh, T.; Tay, Y.; Ang, Y.-S.; Tam, W.-L.; Thomson, A.M.; Lim, B.; Rigoutsos, I. A Pattern-based method for the identification of MicroRNA binding sites and their corresponding heteroduplexes. Cell 2006, 126, 1203-1217. [CrossRef]

76. Kertesz, M.; Iovino, N.; Unnerstall, U.; Gaul, U.; Segal, E. The role of site accessibility in microRNA target recognition. Nat. Genet. 2007, 39, 1278-1284. [CrossRef]

77. Enright, A.J.; John, B.; Gaul, U.; Tuschl, T.; Sander, C.; Marks, D.S. MicroRNA targets in Drosophila. Genome Biol. 2003, 5, R1. [CrossRef]

78. Betel, D.; Koppal, A.; Agius, P.; Sander, C.; Leslie, C. Comprehensive modeling of microRNA targets predicts functional non-conserved and non-canonical sites. Genome Biol. 2010, 11, R90. [CrossRef]

79. Yang, J.H.; Li, J.H.; Shao, P.; Zhou, H.; Chen, Y.Q.; Qu, L.H. starBase: A database for exploring microRNA-mRNA interaction maps from Argonaute CLIP-Seq and Degradome-Seq data. Nucleic Acids Res. 2011, 39, D202-D209. [CrossRef]

80. Li, J.H.; Liu, S.; Zhou, H.; Qu, L.H.; Yang, J.H. starBase v2.0: Decoding miRNA-ceRNA, miRNA-ncRNA and protein-RNA interaction networks from large-scale CLIP-Seq data. Nucleic Acids Res. 2014, 42, D92-D97. [CrossRef]

81. Karagkouni, D.; Paraskevopoulou, M.D.; Chatzopoulos, S.; Vlachos, I.S.; Tastsoglou, S.; Kanellos, I.; Papadimitriou, D.; Kavakiotis, I.; Maniou, S.; Skoufos, G.; et al. DIANA-TarBase v8: A decade-long collection of experimentally supported miRNA-gene interactions. Nucleic Acids Res. 2018, 46, D239-D245. [CrossRef]

82. Chou, C.H.; Shrestha, S.; Yang, C.D.; Chang, N.W.; Lin, Y.L.; Liao, K.W.; Huang, W.C.; Sun, T.H.; Tu, S.J.; Lee, W.H.; et al. miRTarBase update 2018: A resource for experimentally validated microRNA-target interactions. Nucleic Acids Res. 2018, 46, D296-D302. [CrossRef]

83. Peng, S.; Song, C.; Li, H.; Cao, X.; Ma, Y.; Wang, X.; Huang, Y.; Lan, X.; Lei, C.; Chaogetu, B.; et al. Circular RNA SNX29 sponges miR-744 to regulate proliferation and differentiation of myoblasts by activating the Wnt5a/Ca(2+) signaling pathway. Mol. Ther. Nucleic Acids 2019, 16, 481-493. [CrossRef]

84. Zhang, L.; Liu, X.; Che, S.; Cui, J.; Ma, X.; An, X.; Cao, B.; Song, Y. Endometrial epithelial cell apoptosis is inhibited by a ciR8073-miR181a-neurotensis pathway during embryo implantation. Mol. Ther. Nucleic Acids 2019, 14, 262-273. [CrossRef]

85. Shang, J.; Chen, W.M.; Wang, Z.H.; Wei, T.N.; Chen, Z.Z.; Wu, W.B. CircPAN3 mediates drug resistance in acute myeloid leukemia through the miR-153-5p/miR-183-5p-XIAP axis. Exp. Hematol. 2019, 70, 42-54.e43. [CrossRef]

86. Liu, J.; Kong, F.; Lou, S.; Yang, D.; Gu, L. Global identification of circular RNAs in chronic myeloid leukemia reveals hsa_circ_0080145 regulates cell proliferation by sponging miR-29b. Biochem. Biophys. Res. Commun. 2018, 504, 660-665. [CrossRef]

87. Huang, L.; Chen, M.; Pan, J.; Yu, W. Circular RNA circNASP modulates the malignant behaviors in osteosarcoma via miR-1253/FOXF1 pathway. Biochem. Biophys. Res. Commun. 2018, 500, 511-517. [CrossRef] 
88. Feng, C.; Li, Y.; Lin, Y.; Cao, X.; Li, D.; Zhang, H.; He, X. CircRNA-associated ceRNA network reveals ErbB and Hippo signaling pathways in hypopharingeal cancer. Int. J. Mol. Med. 2019, 43, 127-142.

89. Jin, X.; Feng, C.Y.; Xiang, Z.; Chen, Y.P.; Li, Y.M. CircRNA expression pattern and circRNA-miRNA-mRNA network in the pathogenesis of nonalcoholic steatohepatitis. Oncotarget 2016, 7, 66455-66467. [CrossRef]

90. Jiang, C.; Xu, D.; You, Z.; Xu, K.; Tian, W. Dysregulated circRNAs and ceRNA network in esophageal squamous cell carcinoma. Front. Biosci. 2019, 1, 277-290.

91. Campos-Melo, D.; Droppelmann, C.A.; Volkening, K.; Strong, M.J. Comprehensive luciferase-based reporter gene assay reveals previously masked up-regulatory effects of miRNAs. Int. J. Mol. Sci. 2014, 15, 15592-15602. [CrossRef]

92. Tan, S.M.; Lieberman, J. Capture and identification of miRNA targets by biotin pulldown and RNA-seq. Methods Mol. Biol. 2016, 1358, 211-228. [CrossRef]

93. Xie, B.; Zhao, Z.; Liu, Q.; Wang, X.; Ma, Z.; Li, H. CircRNA has_circ_0078710 acts as the sponge of microRNA-31 involved in hepatocellular carcinoma progression. Gene 2019, 683, 253-261. [CrossRef]

94. Ni, H.; Li, W.; Zhuge, Y.; Xu, S.; Wang, Y.; Chen, Y.; Shen, G.; Wang, F. Inhibition of circHIPK3 prevents angiotensin II-induced cardiac fibrosis by sponging miR-29b-3p. Int. J. Cardiol. 2019, 292, 188-196. [CrossRef]

95. Guo, J.; Duan, H.; Li, Y.; Yang, L.; Yuan, L. A novel circular RNA circ-ZNF652 promotes hepatocellular carcinoma metastasis through inducing snail-mediated epithelial-mesenchymal transition by sponging miR-203/miR-502-5p. Biochem. Biophys. Res. Commun. 2019, 513, 812-819. [CrossRef]

96. Li, Y.; Wan, B.; Liu, L.; Zhou, L.; Zeng, Q. Circular RNA circMTO1 suppresses bladder cancer metastasis by sponging miR-221 and inhibiting epithelial-to-mesenchymal transition. Biochem. Biophys. Res. Commun. 2019, 508, 991-996. [CrossRef]

97. Wang, S.; Li, Q.; Wang, Y.; Li, X.; Wang, R.; Kang, Y.; Xue, X.; Meng, R.; Wei, Q.; Feng, X. Upregulation of circ-UBAP2 predicts poor prognosis and promotes triple-negative breast cancer progression through the miR-661/MTA1 pathway. Biochem. Biophys. Res. Commun. 2018, 505, 996-1002. [CrossRef]

98. Han, D.; Li, J.; Wang, H.; Su, X.; Hou, J.; Gu, Y.; Qian, C.; Lin, Y.; Liu, X.; Huang, M.; et al. Circular RNA circMTO1 acts as the sponge of microRNA-9 to suppress hepatocellular carcinoma progression. Hepatology 2017, 66, 1151-1164. [CrossRef]

99. Cherubini, A.; Barilani, M.; Rossi, R.L.; Jalal, M.M.K.; Rusconi, F.; Buono, G.; Ragni, E.; Cantarella, G.; Simpson, H.; Peault, B.; et al. FOXP1 circular RNA sustains mesenchymal stem cell identity via microRNA inhibition. Nucleic Acids Res. 2019, 47, 5325-5340. [CrossRef]

100. Wu, Z.; Huang, W.; Wang, X.; Wang, T.; Chen, Y.; Chen, B.; Liu, R.; Bai, P.; Xing, J. Circular RNA CEP128 acts as a sponge of miR-145-5p in promoting the bladder cancer progression via regulating SOX11. Mol. Med. 2018, 24, 40. [CrossRef]

101. Betel, D.; Wilson, M.; Gabow, A.; Marks, D.S.; Sander, C. The microRNA.org resource: Targets and expression. Nucleic Acids Res. 2008, 36, D149-D153. [CrossRef]

102. Rennie, W.; Kanoria, S.; Liu, C.; Mallick, B.; Long, D.; Wolenc, A.; Carmack, C.S.; Lu, J.; Ding, Y. STarMirDB: A database of microRNA binding sites. RNA Biol. 2016, 13, 554-560. [CrossRef]

103. Rennie, W.; Liu, C.; Carmack, C.S.; Wolenc, A.; Kanoria, S.; Lu, J.; Long, D.; Ding, Y. STarMir: A web server for prediction of microRNA binding sites. Nucleic Acids Res. 2014, 42, W114-W118. [CrossRef]

104. Bartel, D.P. MicroRNAs: Genomics, Biogenesis, Mechanism, and Function. Cell 2004, 116, 281-297. [CrossRef]

105. Grimson, A.; Farh, K.K.; Johnston, W.K.; Garrett-Engele, P.; Lim, L.P.; Bartel, D.P. MicroRNA targeting specificity in mammals: Determinants beyond seed pairing. Mol. Cell 2007, 27, 91-105. [CrossRef]

106. Loeb, G.B.; Khan, A.A.; Canner, D.; Hiatt, J.B.; Shendure, J.; Darnell, R.B.; Leslie, C.S.; Rudensky, A.Y. Transcriptome-wide miR-155 binding map reveals widespread noncanonical microRNA targeting. Mol. Cell 2012, 48, 760-770. [CrossRef]

107. Sticht, C.; De La Torre, C.; Parveen, A.; Gretz, N. miRWalk: An online resource for prediction of microRNA binding sites. PLoS ONE 2018, 13, e0206239. [CrossRef]

108. Rehmsmeier, M.; Steffen, P.; Hochsmann, M.; Giegerich, R. Fast and effective prediction of microRNA/target duplexes. RNA 2004, 10, 1507-1517. [CrossRef]

109. Hammond, S.M.; Bernstein, E.; Beach, D.; Hannon, G.J. An RNA-directed nuclease mediates post-transcritpional gene silencing in Drosophila cells. Nature 2000, 404, 293-296. [CrossRef]

110. Hutvágner, G.; Zamore, P.D. A microRNA in a multiple-turnover RNAi enzyme complex. Science 2002, 297, 2056-2060. [CrossRef] 
111. Hafner, M.; Landthaler, M.; Burger, L.; Khorshid, M.; Hausser, J.; Berninger, P.; Rothballer, A.; Ascano, M., Jr.; Jungkamp, A.C.; Munschauer, M.; et al. Transcriptome-wide identification of RNA-binding protein and microRNA target sites by PAR-CLIP. Cell 2010, 141, 129-141. [CrossRef]

112. Helwak, A.; Kudla, G.; Dudnakova, T.; Tollervey, D. Mapping the human miRNA interactome by CLASH reveals frequent noncanonical binding. Cell 2013, 153, 654-665. [CrossRef]

113. Jungkamp, A.-C.; Stoeckius, M.; Mecenas, D.; Grün, D.; Mastrobuoni, G.; Kempa, S.; Rajewsky, N. In vivo and transcriptome-wide identification of RNA binding protein target sites. Mol. Cell 2011, 44, 828-840. [CrossRef]

114. Grosswendt, S.; Filipchyk, A.; Manzano, M.; Klironomos, F.; Schilling, M.; Herzog, M.; Gottwein, E.; Rajewsky, N. Unambiguous identification of miRNA:target site interactions by different types of ligation reactions. Mol. Cell 2014, 54, 1042-1054. [CrossRef]

115. Chi, S.W.; Zang, J.B.; Mele, A.; Darnell, R.B. Argonaute HITS-CLIP decodes microRNA-mRNA interaction maps. Nature 2009, 460,479-486. [CrossRef]

116. Leung, A.K.; Young, A.G.; Bhutkar, A.; Zheng, G.X.; Bosson, A.D.; Nielsen, C.B.; Sharp, P.A. Genome-wide identification of Ago2 binding sites from mouse embryonic stem cells with and without mature microRNAs. Nat. Struct. Mol. Biol. 2011, 18, 237-244. [CrossRef]

117. Clark, P.M.; Loher, P.; Quann, K.; Brody, J.; Londin, E.R.; Rigoutsos, I. Argonaute CLIP-Seq reveals miRNA targetome diversity across tissue types. Sci. Rep. 2014, 4, 5947. [CrossRef]

118. Boeckel, J.N.; Jae, N.; Heumuller, A.W.; Chen, W.; Boon, R.A.; Stellos, K.; Zeiher, A.M.; John, D.; Uchida, S.; Dimmeler, S. Identification and characterization of hypoxia-regulated endothelial circular RNA. Circ. Res. 2015, 117, 884-890. [CrossRef]

119. Moore, M.; Scheel, T.; Luna, J.; Park, C.; Fak, J.; Nishiuchi, E.; Rice, C.; Darnell, R. miRNA-target chimeras reveal miRNA $3^{\prime}$-end pairing as a major determinant of Argonaute target specificity. Nat. Commun. 2015, 6, 8864. [CrossRef]

120. Ceci, M.; Pio, G.; Kuzmanovski, V.; Dzeroski, S. Semi-supervised multi-view learning for gene network reconstruction. PLoS ONE 2015, 10, e0144031. [CrossRef]

(C) 2019 by the authors. Licensee MDPI, Basel, Switzerland. This article is an open access article distributed under the terms and conditions of the Creative Commons Attribution (CC BY) license (http://creativecommons.org/licenses/by/4.0/). 